\title{
Utilization of Plastic Waste Polyethylene Terephthalate (Pet) as a Coarse Aggregate Alternative in Paving Block
}

\author{
Wiku A. Krasna ${ }^{1, *}$, Rijali Noor $^{1}$, and Denny D. Ramadani ${ }^{2}$ \\ ${ }^{1}$ Lecturer of Faculty of Engineering, Lambung Mangkurat University, Indonesia \\ ${ }^{2}$ Student of Faculty of Engineering, Lambung Mangkurat University, Indonesia
}

\begin{abstract}
PET plastic waste is found everywhere in Banjarbaru City compared to other plastic wastes. It is an excellent prospect to reuse the PET plastic waste. The demand of mountain rock and stone from natural resources increases as happened in Aranio Sub District, Banjar Regency. This research is expected to find one way of suppressing the growth of the number of stone mines or natural stone. Based on SNI 03-0691-1996, the classification of the paving block differentiated according to its usage class, one of which is the $\mathrm{C}$ quality used by pedestrians. PET waste used as a coarse aggregate previously processed into aggregate with the ratio of cement material, fine aggregate, a coarse aggregate of 1:6:4. PET waste is processed by melting PET and forming into aggregates. The paving with PET waste process by a hydraulic press machine and tested for strength after 28 days. The result of weight measurement with the specimen increases the amount of PET in the paving block mixture, the paving weight decreases as well as the compressive strength.
\end{abstract}

\section{Preliminary}

\subsection{Background}

Natural resources are one of the essential assets for country's/national development. Therefore, should be utilized as widely as possible for the interests of the people with attention to sustainability [1]. To anticipating the interest of the community in the field of mining, it is necessary to do the controlling business by implementing the identification of various kinds of damage that may arise so that the development of mining sector can run as expected, especially stone mining. The paving block is one product that utilizes coarse aggregates. The paving block is in high demand in Banjarbaru as a city that is undergoing massive development considering its diverse benefits.

The advantage of using paving its can conserve the groundwater, fast to construct, easy in the installation and maintenance process, it has a variety of shapes that add aesthetic value, and the price is affordable so that can increase the interest of consumers compared to other pavement materials. The need for natural stone as a building material increased as

* Corresponding author: wakrasna@ulm.ac.id 
well as a mountain rock mine (quarry) as happened in Aranio Sub District, Banjar Regency. In this study is expected to find the answer one way of suppressing the growth of the number of stone mines or natural stone.

\subsection{Problem Formulation}

The problem formulations in this research are:

a) Whether of a plastic waste of Polyethylene Terephthalate (PET) can be used as raw material for the paving block?

b) How strong paving blocks use PET waste as coarse aggregate?

c) What is the optimum level of plastic waste to make a paving block achieved the expected compressive strength?

\subsection{Research Purposes}

The purposes of this research are:

a) Investigate the ability of plastic waste as raw material paving block.

b) Investigate the compressive strength of paving block using raw material from PET plastic waste as coarse aggregate.

c) Investigate the level of waste of plastics in the manufacture of paving blocks on the expected quality for pedestrian usage.

\subsection{Research Benefits}

The benefit of this research is to obtain the mechanical behavior of paving block with plastic waste material on compressive strength, to conserve the natural stone as coarse aggregate, and to provide alternative PET plastic waste treatment.

\subsection{Problem Scope}

Limitations of the problem from this research are:

a) The material is plastic waste type Polyethylene Terephthalate (PET) in Banjarbaru.

b) Paving block with the quality plan $125 \mathrm{~kg} / \mathrm{cm}^{2}$ or type $\mathrm{C}$.

c) Using a rectangular paving block with size $20 \times 10 \times 8 \mathrm{~cm}$.

d) The percentages of PET are $0 \%, 25 \%, 50 \%, 75 \%$, and $100 \%$ against the mixed ratio of the coarse aggregate.

e) Strength test is after 28 days.

\section{Literature Review}

\subsection{Paving Block}

Concrete brick or Paving block is a building material composition made from a mixture of Portland cement or similar hydraulic adhesive, water, and aggregate with or without other additives that do not reduce the quality of concrete bricks, is one of the alternative materials of road construction which has advantages among others faster execution time, easy installation and maintenance. Therefore, according to [2], paving blocks must be able to withstand vehicle loads and have aggravation or resistance to slip, especially at crossroads where traction force due to vehicle wheels, either by braking force or acceleration, so the 
paving block condition will quickly damage or worn out. Based on code [3] classification of the paving block (concrete brick) differentiated by class of use (Table 1) as follows:

a) Concrete brick of quality A: used for road

b) Concrete brick of quality B: used for parking lot

c) Concrete brick C: used for pedestrians

d) Concrete brick D: used for parks and other users

Table 1. Quality Requirements for Each Type of Concrete Bricks According to SNI 03-0691-1996

\begin{tabular}{|c|c|c|c|}
\hline \multirow{2}{*}{ Type } & Compressive Strenght $\left(\mathrm{kg} / \mathrm{cm}^{2}\right)$ & \multirow{2}{*}{$\begin{array}{c}\text { Maximum Average } \\
\text { Absorption }\end{array}$} \\
\cline { 2 - 3 } & Average & Minimum & 3 \\
\hline A & 400 & 350 & 6 \\
\hline B & 200 & 170 & 8 \\
\hline C & 150 & 125 & 10 \\
\hline D & 100 & 85 & \\
\hline
\end{tabular}

Source: SNI 03-0691-1996

\subsection{Portland Cement}

Cement is one of the adhesive materials which when mixed with water can bind solid materials such as sand and stone into a compact unity. The nature of the binding of cement determined by the chemical arrangement it contains. The main ingredients contained in cement are lime $(\mathrm{CaO})$, silicate $(\mathrm{SiO} 2)$, alumina ( $\mathrm{Al} 2 \mathrm{O} 3)$, ferrous oxide $(\mathrm{Fe} 2 \mathrm{O} 3)$, magnesite $(\mathrm{MgO})$, and other small oxides [4].

The function of the cement is to bind the aggregate grains to form a solid mass and fill the air cavities between the aggregate grains. Although the composition of cement in concrete is only about $10 \%$, because of its function as a binder, the role of cement becomes essential. Cement used for concrete work should adjust to the planned strength and technical specifications provided.

\subsection{Water}

Water is needed on the manufacture of concrete to trigger the chemical process of cement, moistens aggregate and provides ease in concrete work. Water used as a concrete mixture is not containing harmful compounds. Generally, drinking water can use in the mixture. Water containing harmful, contaminated, silt, oil, sugar, or chemical forming materials against the strength and properties of cement binding, this may disrupt the attractiveness between the aggregate and the cement paste and may adversely affect the working of a mixture. Since the cement paste character is only the product of a chemical reaction between cement and water, it is not the proportion of water relative to the overall mixture of dry materials under consideration, but only the proportion of water relative to cement. If excessive water will cause many water bubbles after the hydration process, while too little water will cause the hydration process is not achieved entirely, so that will affect the strength of the concrete.

The water used shall be eligible according to [5], the water requirements as a building material shall meet the following criteria:

a) Water used in concrete mixtures shall be clean and free of defective materials containing oils, acids, alkalis, salts, organic materials, or other substances harmful to concrete or reinforcement.

b) The mixing water used in prestressed concrete or on concrete in which aluminum embedded, including the free water contained in the aggregate, shall not contain harmful ions of chlorides. 


\subsection{Fine Aggregate}

The fine aggregate referred to in the making of this paving block is sand. According to [6] fine aggregate is an aggregate of natural sand as a result of the disintegration of artificial rocks or sand produced by stone breaking tools and has a grain of $4.76 \mathrm{~mm}$. The quality of sand used as a concrete component plays a vital role in determining the quality of the resulting concrete because the sand fills most of the volume of concrete. The characteristics of granules and gradations and the interlocking of sand are very good; it can affect the strength and durability of the concrete. [7].

\subsection{Coarse Aggregate}

Coarse aggregate is the main component of nature constructing concrete structures. It plays an important role in the process of helping the concrete. The coarse aggregate properties affect the hardened end strength of the concrete and its resistance to disintegration, weather, and other damaging effects. Coarse aggregates of minerals should be clean to dirty organic materials and should be well attached to cement jelly. The coarse aggregate is composed of rock fragments exceeding $5 \mathrm{~mm}$ in size so that the maximum size is justified for certain concrete works, by [8].

Coarse aggregates in paving blocks can provide optimum strength when clean (containing no harmful substances such as free of mud, clay, and organic materials) in order not to reduce the strength of the concrete.

\subsection{Plastic Waste Polyethylene Terephthalate (PET)}

The use of plastic materials increasingly widespread because of its strong and not easily damaged by weathering. The development of plastic products in Indonesia has been very rapid in the last two decades by expanding into all kinds of human needs, from basic needs such as household necessities to accessories in luxury cars. The types of plastics encountered in the Indonesian domestic market are Polypropylene (PP), Polyethylene (PE), Polystyrene (PS), Polyvinyl Chloride (PVC), Acrylonitrile Butadiene Styrene (ABS), and Polyethylene Terephthalate (PET). Materials such as alkyd resin, polyol, melamine resin, unsaturated polyester resin, and polyester have been produced locally while other products are still obtained from outside Indonesia [9].

PET is a polyester family just like PC. PET film is clear, strong, tough, dimensionally stable, fireproof, non-toxic, permeable to gas, aroma or low water. PET engineer resin has a combination of properties: strength (strength) is high, stiffness, dimension stable, chemical and heat resistant, and have good electrical properties. PET has a low water vapor absorption, as well as water absorption. PET can process by extrusion process at hightemperature $518-608^{\circ} \mathrm{F}$, but it also processed by injection molding technique or blow molding. Before printing the PET resin should be dried first (maximum moisture content of $0.02 \%$ ) to prevent the hydrolysis process during printing.

\subsection{Compressive strength On Paving Block}

To know the quality of paving block required testing of compressive strength. Based on the methodology of concrete compressive strength test [10], the strength calculates by the following formula: 


$$
\text { Compressive strength }=\frac{P}{L}
$$

Explanation:

$\mathrm{P}=$ Maximum load to the specimen,

$\mathrm{L}=$ Area

The concrete is brittle hence it is better in compression than in tension. The high compressive strength of concrete is usually related to good material properties. Concrete with high compressive strength mostly uses in special structures such as railway bearing, pile, beams, and columns in high rise buildings. The strength of concrete depends on three characteristics:

a) The strength of paste (water and cement)

b) Adhesive capability between the paste and surface of aggregate grains, and

c) The strength of aggregate

In this study carried out a strong test press after the specimens are 28 days, according to previous research which is implemented by [11] concluded after 28 days is the right age for concrete testing.

\section{Research Methods}

\subsection{Research design}

This study is intended for knowhow ability waste plastics processed as coarse aggregate on concrete or paving block. Research conducted in the form experiments on a laboratory scale use a compressive strength test on paving block specimens. Then the data the resulting analyzed the effect of plastic waste as a coarse aggregate on the expected compressive strength.

\subsection{Research sites}

The locations of this research are:

a) The location of the raw material research in the form of plastic waste in a sports center like a building sports and domestic waste at Banjarbaru, South Kalimantan.

b) Concrete workshop "Martha Paving" in Martapura, Banjar District, Kalimantan South.

c) Laboratory Structure and Materials Faculty of Engineering, University of Lambung Mangkurat.

\subsection{Object of research}

As the object of research is PET plastic waste material process becomes a coarse aggregate on the paving block.

\subsection{Research Framework}

The flowchart for this research is as follows: 


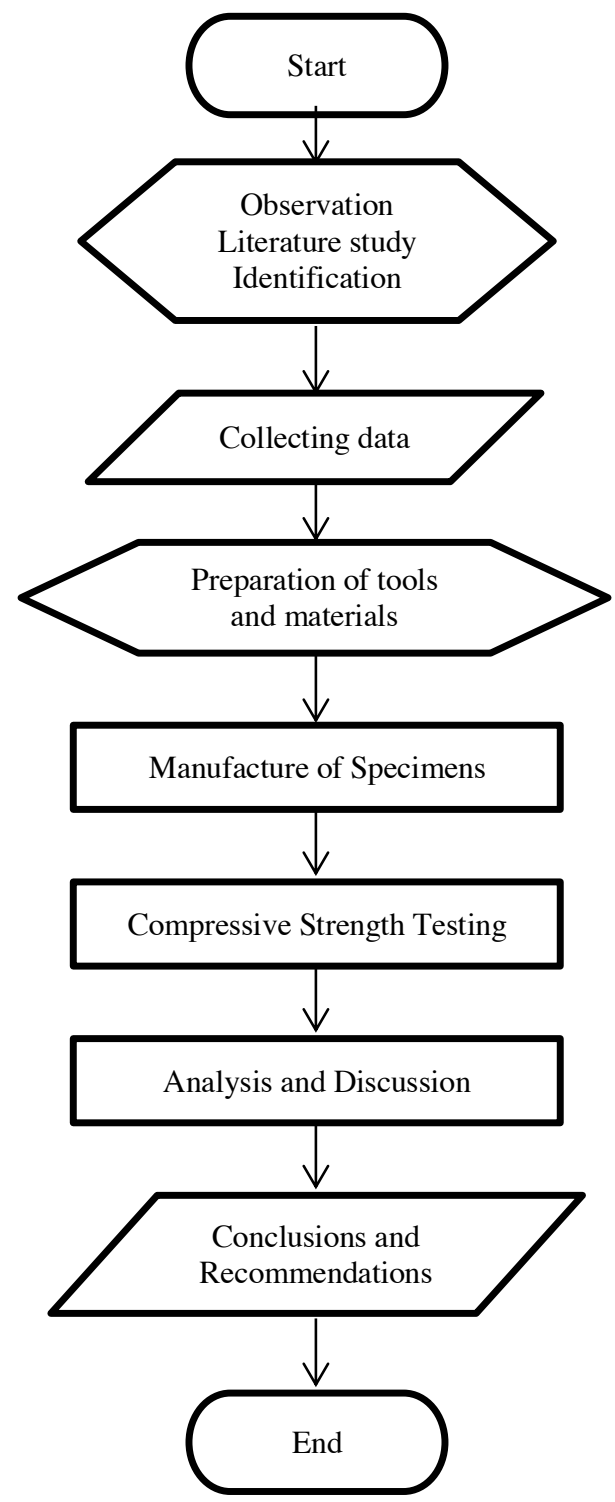

Fig 1. Flow Chart of Research Design

\subsection{Preliminary phase}

Collect data by studying books and several research journals on concrete, compressive test, concrete brick, plastic, and waste plastic management.

\subsection{Preparation phase}

The collection of research materials, especially plastic waste which is further compacted, chopped, then formed by melting, after which it is broken up to resemble a coarse aggregate. 


\subsection{Manufacture of test specimens}

The manufacture of the specimens done in a private concrete plant. Total test specimens were 15 specimens, there were five different aggregate content of different plastic waste, with the correct composition based on [12] research on cement, fine aggregate and coarse aggregate, i.e., 1:6:4. The paving block manufacture using the compressive pressing machine.

\section{Research Result}

The making of test specimens totals 15 pieces. The size of $20 \times 10 \times 8 \mathrm{~cm}$ with the ratio of cement material, fine aggregate, and coarse aggregates is 1:6:4 according to previous research by [12] which concludes that this is the right material comparison for coarse aggregate testing. The amount of PET as the independent variable is $0 \%, 25 \%, 50 \%, 75 \%$ and $100 \%$ against the coarse aggregate ratio used. The naming of the specimen's code as follows; PB 1 for 0\% PET, PB2 for 25\% PET, BP3 for 50\% PET, PB4 for $75 \%$ PET, and, PB5 for $100 \%$ PET. All ingredients mixed evenly with a little water added, then put into paving block mold before pressed by using the hydraulic machine.

\subsection{Weight Object}

The results of paving block weight measurement based on a mixture of cement, water, fine aggregate (sand), coarse aggregate (crushed stone) and PET aggregate. Paving block treatment was done by a soaking process with water for 27 days after paving block was made, then dried for 24 hours. The results obtained as shown in Table 2.

Table 2. Weight Measurement of Test Items

\begin{tabular}{|c|c|c|c|c|c|}
\hline \multirow{2}{*}{ Code } & \multicolumn{3}{|c|}{ Specimen's weight $(\mathrm{kg})$} & \multirow{2}{*}{$\begin{array}{l}\text { Standard } \\
\text { deviation }\end{array}$} & \multirow{2}{*}{ Average $(\mathrm{kg})$} \\
\hline & A & B & $\mathrm{C}$ & & \\
\hline PB1 & 3,6 & 3,5 & 3,55 & 0,050 & 3,55 \\
\hline PB2 & 3,4 & 3,3 & 3,3 & 0,058 & 3,33 \\
\hline PB3 & 3.2 & 3,15 & 3,3 & 0,076 & 3,22 \\
\hline PB4 & 3.0 & 3.0 & 3.1 & 0,058 & 3,03 \\
\hline PB5 & 2.7 & 2,85 & 2,65 & 0,104 & 2,73 \\
\hline
\end{tabular}

Source: calculation

The weight value of the paving block seen in the average weight of each composition. The greater the ratio of the coarse aggregate substitution of paving block plastic waste, the lighter the weight of the paving block as shown in Fig. 2. In the weight measurement with the test specimen code "PB1" as the comparison, the PB2 specimens have a weight loss of $6.2 \%$, the PB3 reached 9,3\%, PB4 reached 14,65\%, and PB5 reached $23 \%$. 


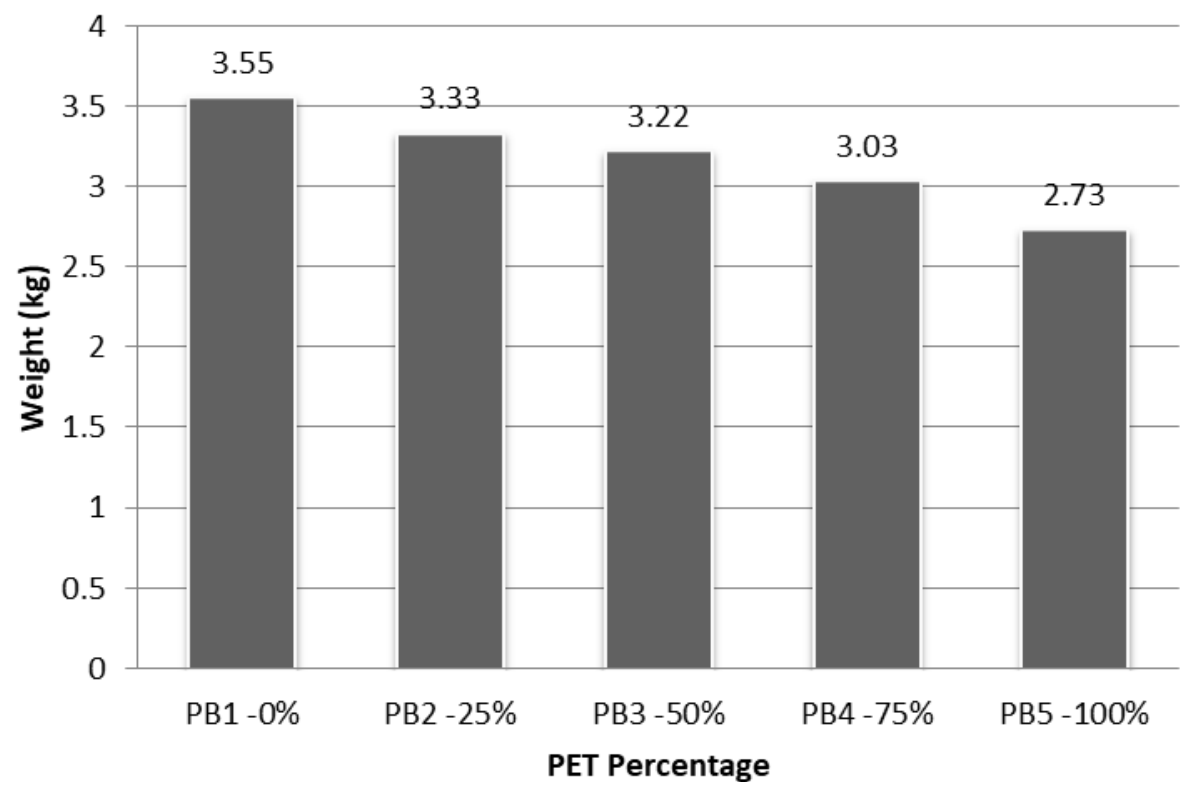

Fig 2. The Mean Weight Relation of Comparison of PET Coarse Aggregate

\subsection{Compressive Strength}

The result of concrete brick compressive strength test was calculated using an equation based on [10] obtained result data like graph as shown in Fig 3. as follows

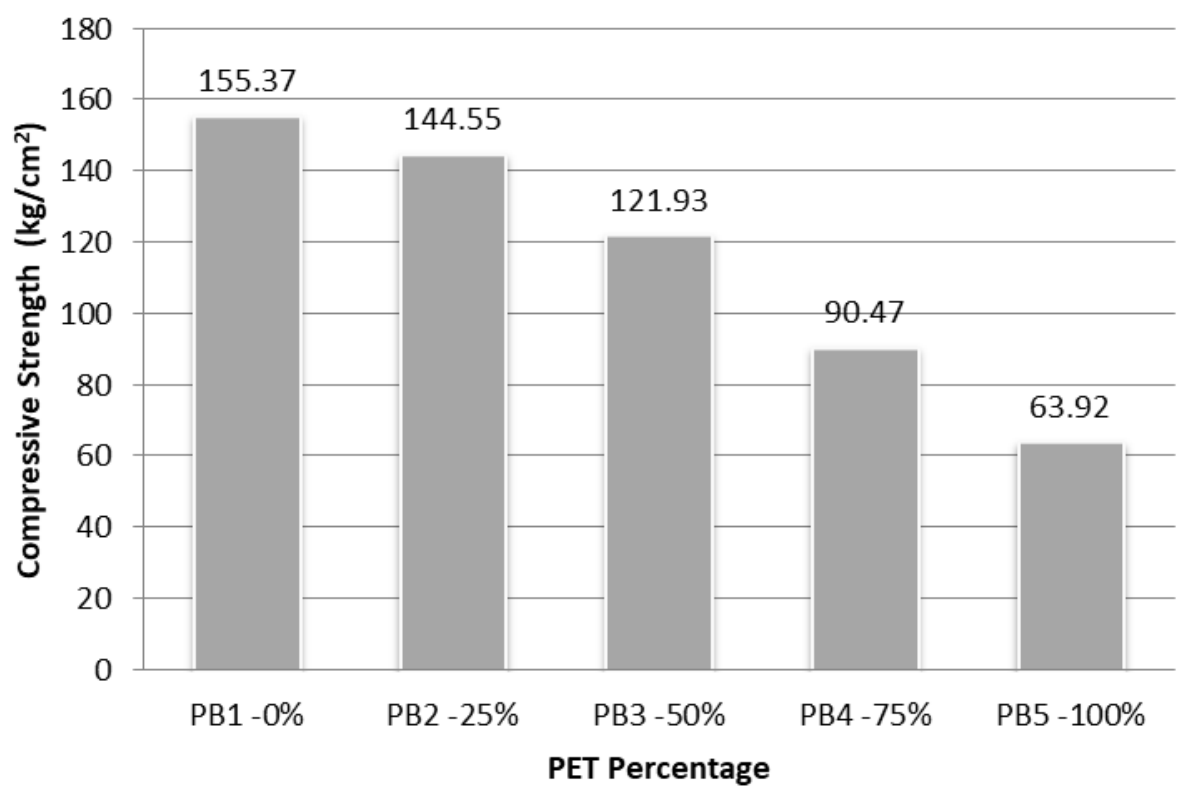

Fig 3. Compressive Strength Comparison of PET Coarse Aggregate

From the graph in Fig. 3 shows a decrease in compressive strength due to the addition of PET composition. From the graph, in Fig. 4 the quality criteria of paving block produced based on [3] are only PB2 (25\%) specimens with a mean of $144.5 \mathrm{~kg} / \mathrm{cm}^{2}$ compressive 
strength that satisfies the quality of $\mathrm{C}$ type paving block that can be used by pedestrians. PB3 (50\%) and PB4 (75\%) test specimens with respectively a compressive strength of $121.93 \mathrm{~kg} / \mathrm{cm}^{2}$ and $90.47 \mathrm{~kg} / \mathrm{cm}^{2}$ meet the quality of D type paving block that may use in parks and other uses.

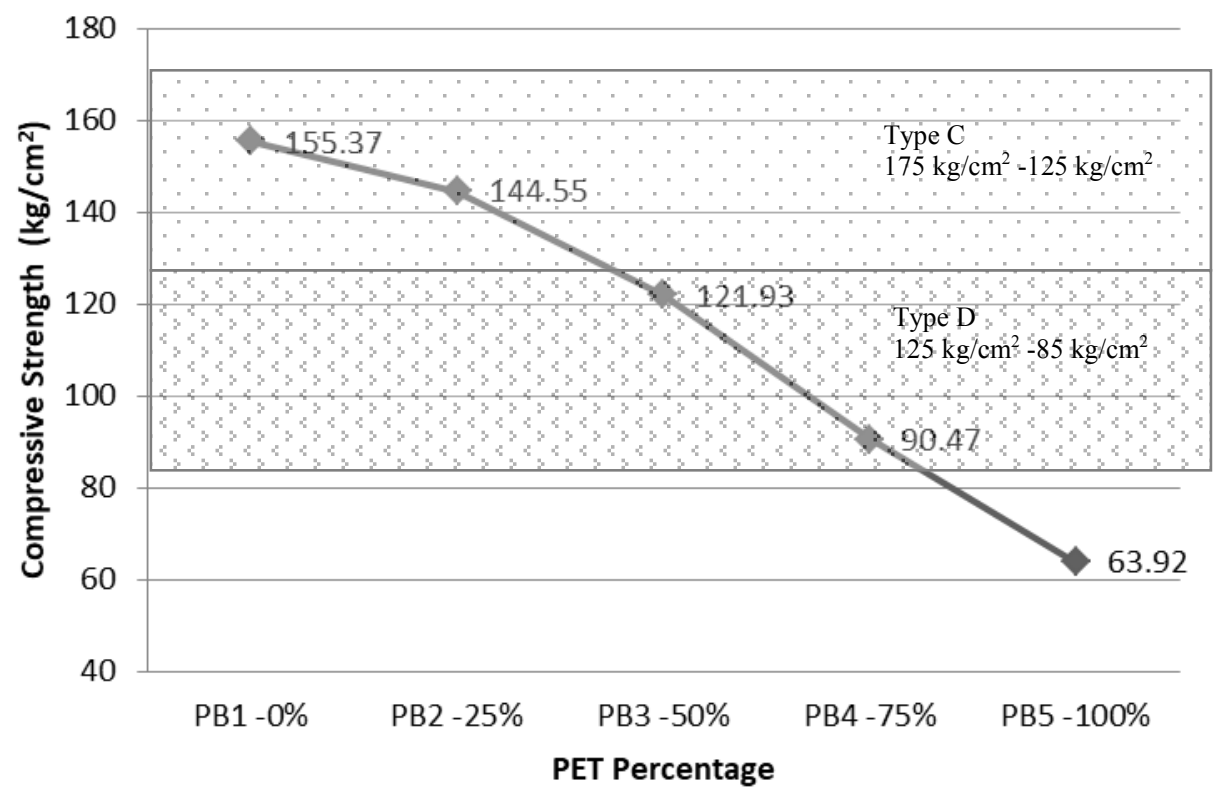

Fig 4. Relationship of Classification of Average Quality to Comparison of Addition of Pure Coarse Aggregate on Making Paving Block

Based on this research, the PET waste can substitute coarse aggregate in paving blocks. Paving blocks with PET waste can meet category C (PB2) with a weight reduction of $6.2 \%$ and a reduction in strength of only $7 \%$.

\section{Closing}

\subsection{Conclusion}

From the results of research and data analysis, it concluded as follows:

a) The coarse aggregate of Polyethylene Terephthalate (PET) can be used as an alternative material to substitute some natural stone in Paving Block mixture because 4 out of 5 specimens from the average of compressive strength test according to [3] Categorized as a good quality paving and with good production. In the weight measurement with the specimen's code PB1 as a comparison, the specimen's of PB2 test occurs weight loss reaches $6.2 \%$, the specimen's PB3 reaches $9.3 \%$, and the specimen's PB4 reaches $14.65 \%$.

b) On the composition ratio of cement material: fine aggregate: a coarse aggregate of 1: 6: 4 loaded with PET coarse aggregate, then obtained test value of compressive strength of specimen's code PB2 (25\%) $144.55 \mathrm{~kg} / \mathrm{cm}^{2}$, PB3 $(50 \%) 121.93 \mathrm{~kg} / \mathrm{cm}^{2}$, the specimen's code PB4 $(75 \%) 90.47 \mathrm{~kg} / \mathrm{cm}^{2}$, and the specimen's code PB5 $(100 \%) 63.92 \mathrm{~kg} / \mathrm{cm}^{2}$.

c) Based on [3], only PB2 (25\%) code specimens with a mean of $144.5 \mathrm{~kg} / \mathrm{cm}^{2}$ compressive strength that meets the quality of $\mathrm{C}$ concrete brick. 


\subsection{Recommendations}

The recommendations from this research are:

a) Further research needs to use other parameters, such as a shock test, water absorption, and tensile test.

b) To improve the compressive strength, suggested adding cement improvement of compressive strength by adding the composition ratio on the cement inside, so the use of cement as the glue is increasingly significant.

c) PET plastic waste processing required being a better coarse aggregate, which can make coarse aggregates of solid and large granules planned.

\section{References}

1. Risyanto, J., Suratman Woro, Yusron Halim, Sriyono. Identifikasi Kerusakan Lingkungan Akibat Penambangan Bahan Galian Golongan C Di Kecamatan Paciran Kabupaten Lamongan dan Kecepatan Panceng Kabupaten Gresik Propinsi Jawa Timur. Prosiding Seminar Hasil-Hasil Fakultas Geografi UGM. (2001).

2. Gharif H.A, El, Sudarmoko, dan Djoko Suityo. Pengaruh Penggunaan Berbagai Variasi Panjang Serat Polyethylene Konsentrasi 1,6\% Pada Sifat-Sifat Paving Block Dengan Batu dan Silica Fume. Universitas Gadjah Mada. (2010).

3. Standar Nasional Indonesia (SNI) 03-0691-1996. Bata Beton (Paving Block). Badan Standardisasi Nasional. (1996).

4. Da Cruz, Johannes. Analisa Kuat Tekan Beton K-175 dengan Campuran Serbuk Kapur dan Serbuk Batu Bata Untuk Penghematan Penggunaan Semen sebagai Bahan Pengikat Dasar. Universitas Komputer Indonesia. (2012).

5. Standar Nasional Indonesia (SNI) 03-2847-2002. Tata Cara Perhitungan Struktur Beton Untuk Bangunan Gedung. Badan Standardisasi Nasional. (2002).

6. Standar Nasional Indonesia (SNI) 03-6820-2002. Spesifikasi Agregat Halus untuk Pekerjaan Adukan dan Plesteran dengan Bahan Dasar Semen. Badan Standardisasi Nasional. (2002).

7. Maulanie, Estutle, Syahrudin Ardiansa, dan Fidyanah Ashri. Pembuatan Paving Block Dengan Campuran Pulverized Fly Ash dan Pasir Lumajang. Seminar Nasional Aplikasi Teknologi Prasarana Wilayah. Surabaya. (2010).

8. British Standard (BS) 882:1992. Specification For Aggregates From Natural Sources For Concrete. British Standards Institution. London. (1992).

9. Sahwan F. L., Joko Heru M., Sri Wahyono, dan Lies A Wisoyodharmo. Sistem Pengelolaan Limbah Plastik Di Indonesia. Badan Pengkajian dan Penerapan Teknologi Lingkungan. (2005).

10. Standar Nasional Indonesia (SNI) 03-1974-1990. Metode Pengujian Kuat Tekan Beton. Badan Standardisasi Nasional. (1990).

11. Sundari, Yayuk Sri. Pengaruh Umur Beton Terhadap Nilai Kuat Tekan Pada mutu Beton. Universitas 17 Agustus 1945. Samarinda. (2012)

12. Mallisa, Harun. Pengaruh Batu Pecah Terhadap Kuat Tekan Paving Block. Universitas Tadulako. Palu. (2006). 